\title{
SMART CANTEEN : PERILAKU MENGATUR POLA MAKAN DENGAN MEMBACA NILAI NUTRISI \\ (CONVENTIONAL DEEP LEARNING NEURAL NETWORK)
}

\author{
Ari Purno Wahyu ${ }^{1}$, Heri Heryono ${ }^{2}$, M. Benny Chaniago ${ }^{3}$, Dani Hamdani ${ }^{4}$ \\ Prodi Informatika Universitas Widyatama ${ }^{1}$ \\ Prodi Bahasa Inggris Universitas Widyatama ${ }^{2}$ \\ Prodi Sistem Informasi Universitas Widyatama ${ }^{3,4}$ \\ Universitas Widyatama \\ Jl. Cikutra no 204A, Kota Bandung \\ ari.purno@widyatama.ac.id ${ }^{1}$ heri.heryono@widyatama.ac.id ${ }^{2}$ benny.chaniago@widyatama.ac.id $^{3}$ \\ dani.hamdani@widyatama.ac.id ${ }^{4}$
}

\begin{abstract}
Abstrak
Kesehatan merupakan bagian terpenting bagi kita dimana pengaruh atau datangnya penyakit melalui pola makan, terlebih bagi kita yang memiliki kesibukan yang luar biasa padatnya tentu saja tidak ada waktu untuk sarapan dan lebih memilih makanan cepat saji yang tersedia banyak di kantin atau kafe. Hal ini bukan berarti makanan cepat saji tidak sehat, hal ini akan menjadi masalah jika terlalu berlebih dan tidak memperhatikan takaran saji atau kandungan nutrisi yang ada pada makanan tersebut. Beberapa cara bisa dilakukan dengan menjaga sikap pola makan misalkan dengan diet atau menggunakan aplikasi perhitungan nutrisi yang ada di pasaran dan gratis untuk diunduh. Jenis aplikasi ini masih kurang efektif dimana aplikasi tersebut masih merupakan perkiraan saja dan tidak bisa digunakan secara realtime.

Penelitian sebelumnya bisa menggunakan teknik computer vision dengan menggunakan image sebagai alat pembaca dari makanan yang akan kita santap. Aplikasi tersebut mampu membaca kandungan nutrisi sekaligus harga makanan, teknik pengolah image yang digunakan menggunakan metode Deep Learning Neural Network, algoritma ini terbukti memiliki akurasi dan pembacaan data yang tinggi dibandingkan algoritma yang lain. Aplikasi dengan Neural Network yang berbasis image bisa diimplementasikan pada mesin kasir di kantin atau cafe dan bisa dibuat dalam bentuk perangkat mobile sehingga lebih mudah digunakan.
\end{abstract}

Teknik komputerisasi dengan Deep Learning Neural Network terbukti bisa diterapkan di kantin dan café. Tempat makan tersebut hanya menyiapkan sebuah komputer lengkap dengan kamera dan server, kemudian pembeli akan mendatangi kasir untuk melakukan pembayaran, komputer tersebut akan memberikan informasi terhadap takaran nutrisi yang disajikan bahkan estimasi uang yang harus dibayar, cakupan kalori yang tersaji pada hidangan yang kita pilih akan ditampilkan secara detail. Teknik image processing memiliki kemampuan dan kehandalan dengan akurasi yang tinggi, teknologi ini untuk mendukung konsep aplikasi pembacaan nilai nutrisi dengan akurasi hingga $90 \%$.

Kata kunci:

Pola Makan, Kalori, Nutrisi Informasi, Image Processing, Deep Learning, Neural Network

\begin{abstract}
Health is the most important part for us where the influence or arrival of disease through eating patterns, especially for those of us who have a very busy schedule, of course there is no time for breakfast and prefer fast food that is available in many cafes or cafes. This does not mean fast food is not healthy, this will be a problem if it is too excessive and does not pay attention to the amount of food or nutrient content that is in the food. Some ways can be done by maintaining the attitude of a diet for example by dieting or using nutritional calculation applications that are on the market and free to download. This type of application
\end{abstract}


is still less effective where the application is still only an estimate and cannot be used in realtime.

Previous research can use computer vision techniques by using images as a reader of the food we will eat. The application is able to read the nutritional content as well as the price of food, image processing techniques used using the Deep Learning Neural Network method, this algorithm is proven to have high accuracy and data readings compared to other algorithms. Applications with image-based Neural Networks can be implemented on cashiers in canteens or cafes and can be made in the form of mobile devices so that they are easier to use.

Computerized techniques with a Deep Learning Neural Network can prove to be applied in canteens and cafes. Places to eat is only to prepare a computer complete with a camera and server, then the buyer will come to the cashier to make a payment, the computer will provide information on the nutritional quantities that are served even the estimated money to be paid, the calorie coverage presented on the dishes we choose will be displayed in detail. Image processing techniques have the ability and reliability with high accuracy, this technology is to support the application concept of reading nutritional values with an accuracy of up to $90 \%$.

Keywords:

Diet, Calories, Nutrition Information, Image Processing, Deep Learning, Neural Network.

\section{Pendahuluan}

Kantin saat ini menjadi sebuah kebutuhan yang mutlak dan menjadi suatu fasilitas pendukung banyak ditemui di perkatoran dan fasilitas publik lainya. Kantin modern saat ini mampu menyesuaikan kebutuhan menu pembeli dan menyajikan harga terjangkau. Dengan adanya fasilitas kantin memudahkan mahasiswa atau karyawan untuk istirahat dan bersantap siang melepas kesibukan saat jam kerja. Keunggulan kantin modern saat ini mampu menyajikan tempat yang rapih dan bersih sehingga kita betah dan berlama-lama di tempat tersebut bahkan terdapat kantin yang menyediakan akses fasilitas wifi.

Bagi kita yang memiliki kesibukan yang sangat padat, penting untuk makan secara teratur dan sesuai dengan asupan gizi dan kalori. Terkadang saat kita makan di kantin tidak begitu memperhatikan kebutuhan gizi tubuh kita, terkadang kita mengambil makanan dengan takaran yang berlebihan dan menyebabkan kita mengalami gangguan kesehatan seperti kolestrol tinggi, darah tinggi atau darah rendah. Demikian juga pemilik kantin tidak ingin calon pembeli menjadi sakit setelah menyantap makanan, dengan adanya konsep kantin pintar bukan bermaksud melarang kita untuk menyantap makanan yang enak tetapi lebih kepada bagaimana cara kita menyeimbangkan menu yang kita makan dengan serat dan nilai gizi yang seimbang, sebagai contoh jika kita mengambil menu sop iga maka sistem akan menampilkan jumlah kalori yang tesedia, jika ternyata tinggi kadar kolestrolnya kita bisa menyeimbangkan dengan memesan salad atau buah-buahan. Konsep kantin pintar ini mampu manajemen kesehatan kita sekaligus cakupan kalori yang diperlukan.

\section{KAJIAN LITERATUR}

Menjaga pola makan dalam bentuk diet adalah sebuah hal biasa yang kita lakukan dan merupakan usaha untuk mempertahankan pola hidup sehat. Upaya lain adalah dengan membaca nilai takaran dan asupan gizi pada makanan yang kita konsumsi, kemampuan melakukan diet ini membutuhkan waktu dan kemauan yang kuat, usaha diet dengan metode tersebut terkadang membuat kita menjadi tidak nyaman dan dirasa kurang efektif dan efisien. Pada penelitian sebelumnya telah dibuat sebuah aplikasi untuk membaca nilai nutrisi dengan metode data logging. Pada penelitian ini mampu memberikan sebuah solusi dan bisa digunakan secara individu, diharapkan dengan data logging mampu menjaga pola makan. Aplikasi pembacaan nilai gizi ini sangat berguna jika kita melakukan perjalanan keluar negeri dan sulit mengidentifikasi nilai nutrisi pada makanan karena bentuk dan merk yang berbeda (Doyen SAHOO;Hao WANG;Ke SHU;Xiongwei WU;Hung LE, 2019). Makanan bisa mempengaruhi pola kehidupan kita dan memiliki dampak yang beragam dan aspek pengaruh lainnya (Weiqing Min; Shuqiang Jiang; Linhu Liu; Yong Rui; Ramesh Jain, 2018).

Pada penelitian sebelumnya metode pengenalan makanan menggunakan sebuah fitur image. Data makanan tersebut diproses dengan menggunakan metode Deep Learning Neural Network dengan membagi beberapa data menjadi data trainng. Fitur ini memiliki karakteristik cara kerja yang sama dengan penglihatan manusia yang direpresentasikan kembali

Ari Purno Wahyu, Heri Heryono, M. Benny Chaniago, Dani Hamdani 
dengan bantuan komputer (Jeff Donahue, Yangqing Jia; Oriol Vinyals; Judy Hoffman; Ning Zhang;Eric Tzeng; Trevor Darrell;, 2014) (Jason Yosinski; Jeff Clune; Yoshua Bengio; Hod Lipson).

Pada penelitian sebelumnya pernah dilakukan di Singapura dengan membuat sebuah sistem deteksi makanan menggunakan image. Metode ini menggunakan data sample dalam bentuk acak, dataset yang digunakan adalah jenis makanan yang beredar di Singapura mulai dari nasi goreng, ayam goreng, es krim dan lain-lain. Dari data tersebut dilakukan proses klasifikasi dan pengkategorian beberapa makanan, mulai dari makanan yang berbentuk gorengan, buahbuah dan jenis minuman. Total data yang terkumpul pada penelitian tersebut mencapai 1.166 data, tetapi terdapat beberapa data makanan yang akan sulit diidentifikasi seperti kadar gula pada satu cangkir kopi, sehingga nilai nutrisi pada jenis minuman masih sulit diidentifikasi. Untuk mengatasi masalah tersebut penelitian dilakukan dengan menggunakan nilai kadar nutrisi dan gula dengan minuman yang sejenis, dari 1.166 makanan yang diambil datasetnya memiliki 756 kategori dan bertambah hingga 10.000 dataset yang berbentuk image atau disebut juga sebagai imageSet (Jia Deng ; Wei Dong; Richard Socher; Li-Jia Li;Kai Li; Li Fei-Fei, 2009).

Sistem identifikasi nutrisi makanan menggunakan aplikasi komputer sangat penting dan telah menjadi sebuah isu beberapa tahun belakangan ini, karena komsumsi makanan akan sangat berpengaruh dan berdampak pada kesehatan. Beberapa penyakit yang ditimbulkan oleh pola makanan sangat berbahaya seperti yaitu obesitas, diabetes, jantung koroner, apnea, cancer, asma serta osteoporosis (Dixon, J. B. ;, 2010). Metode deep learning memiliki nilai akurasi yang tinggi dalam mengenali pola data dalam bentuk image. Pada percobaan tahun 2016 teknik ini memiliki nilai akurasi mencapai $78.77 \%$ dalam membaca data imageNet dan akurasi $67.57 \%$ untuk membaca 256 dataset (Lowe, D.G;, 1999).

Identifikasi jenis makanan untuk mengetahui kandungan kalori memiliki tantangan tersendiri, tetapi proses penerapan metode tersebut masih terus dikembangkan. Identifikasi ini sangat berguna pada makanan cepat saji sehingga takaran dan jumlah konsumsinya bisa diatur, dan kita sendiri bisa memutuskan makanan tersebut baik atau tidak bagi kesehatan tubuh kita. Jenis data yang digunakan pada penelitian sebelumnya merupakan kombinasi dari PFID dan Deep Learning Neural Network dengan proses klasifikasi objek menggunakan SVM. Metode deep learning memiliki struktur data yang banyak sehingga sangat mudah digunakan untuk mengekstraksi fitur data dari image yang lebih komplek, SVM akan mengklasifikasikan data dengan metode non-linier. Pada percobaan tersebut disimpulkan bahwa SVM memiliki akurasi yang tinggi dibandingkan dengan metode yang lain (Amatul Bushra Akhi; Farzana Akter; Tania Khatun, 2018).

Menggunakan data dari sebuah foto makanan biasanya dipergunakan untuk menilai perilaku seseorang dalam menjaga kesehatan. Beberapa aplikasi banyak di pasaran dipergunakan untuk menghitung jumlah asupan nutrisi terhadap makanan yang dikonsumsi. Alat ini menjadi sebuah mekanisme dan keharusan untuk memantau asupan gizi seseorang terutama bagi orang yang memiliki kondisi obesitas, hipertensi dan gangguan kesehatan lainnya (A., T. , 1992).

\section{Analisis dan Perancangan}

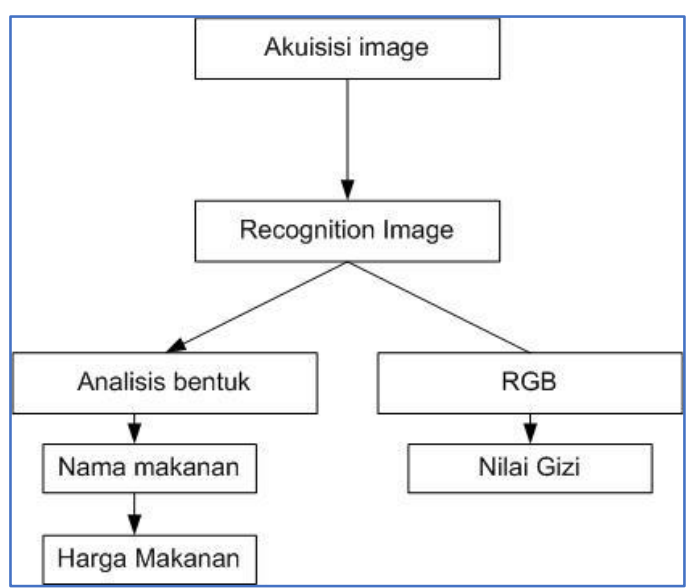

Gambar 1 Tahapan metode pembacaan nutrisi

Pada gambar 1 adalah tahapan metode pembacaan nilai nutrisi dengan metode image processing. Metode ini akan mendata jenis makanan dan daftarnya yang ada di tempat makan. Tahapan metode pembacaan nutrisi tersebut adalah sebagai berikut:

\section{Akusisi image}

Pada proses ini adalah lebih pada penentuan alat yang digunakan untuk mengambil gambar makanan. Inputan kamera terkoneksi dengan komputer yang ada pada kasir kantin. Pada bagian ini dilakukan proses

Ari Purno Wahyu, Heri Heryono, M. Benny Chaniago, Dani Hamdani 
kalibrasi antara jarak makanan yang ada pada piring saji dengan tinggi kamera.

\section{Recognition image}

Pada proses ini sistem image processing mulai membedakan bentuk tiap jenis makanan beserta alat makannya, seperti piring atau mangkok. Sistem berfungsi mengenali jenis makanan dari takarannya kemudian dilakukan proses analisis bentuk.

\section{Analisis bentuk}

Pada proses ini dilakukan proses pembedaan tiap bentuk makanan, sehingga kesalahan sistem dalam membaca jenis makanan bisa diminimalisir. Sistem image processing berfungsi untuk membaca jenis, bentuk dan ukuran makanan dengan menggunakan teknik deteksi tepi, selanjutnya dilakukan proses sortasi kembali menggunakan warna makanan dengan metode RGB (Red, Green, Blue).

\section{4. $R G B$}

Pada bagian ini merupakan bagian terpenting setelah analisis bentuk, kemudian jenis makanan akan dianalisis dari segi warna, sebagai contoh warna makanan berwarna putih banyak mengandung karbohidrat seperti nasi, roti, mie dan susu, sedangkan makanan berwarna cokelat banyak mengandung lemak seperti cokelat, daging rebus, sosis dan ikan. Melalui pembeda warna tadi sistem image processing akan menghitung jumlah kalori dengan volume dan diameter makanan yang diambil atau disajikan, makin banyak jenis makanan yang diambil maka ukuran nutrisinya akan semakin besar pula.

Implementasi pengujian dilakukan dengan mendata dan mengambail gambar setiap makanan yang akan kita santap. Output dari sistem ini adalah munculnya jumlah makanan dan takaran saji, nilai dari setiap takaran saji berbeda pada tiap hidangan.

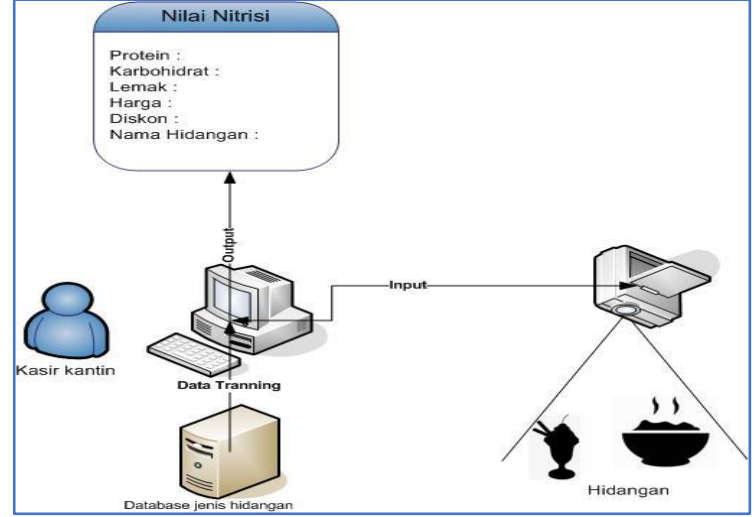

Gambar 2 Konfigurasi perangkat keras

Sampel menggunakan data secara acak. Sistem ini membaca deteksi tepi dan bentuk serta warna makanan, sebagai contoh pola bentuk digunakan untuk mengenali jenis makanan seperti mie yang umumnya berbentuk kecil dan memanjang atau baso yang berbentuk lingkaran dan bulat, sedangkan deteksi warna digunakan untuk mendeteksi warna makanan. Indikasi warna digunakan biasanya untuk mendeteksi warna sayuran atau buah yang umumnya berwarna hijau, sedangkan warna merah indikasi makanan seperti daging dan makanan merah, sedangkan warna kuning untuk makanan yang banyak mengandung protein seperti roti dan mie. Setiap data yang diambil pada hidangan akan dilakukan proses segmentasi berdasarkan warna dan ukuran.

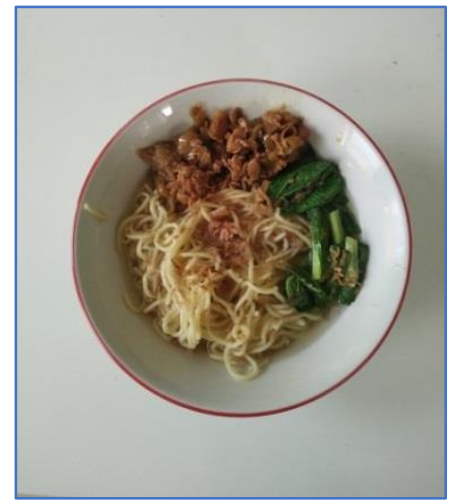

Gambar 3 Takaran saji hidangan

\section{Keterangan:}

Pada gambar 3 adalah hidangan yang akan dijadikan sample data pengujian. Aplikasi akan mendeteksi jumlah kalori dan nilai gizi yang muncul secara visual pada takaran saji. 


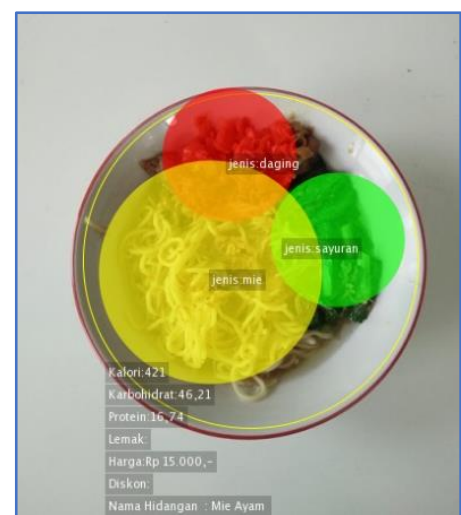

\section{Gambar 4 Data image yang sudah diekstraksi}

\section{Keterangan:}

Pada gambar 4 adalah proses pengujian informasi takaran saji. Takaran saji ditampilkan secara visual oleh komputer, sistem komputer menampilkan jenis hidangan yang disajikan serta menampilkan jumlah nilai kalori, komposisi masukan dan nama makanan serta harganya. Warna lingkaran kuning merupakan nilai komposisi mie, warna hijau makanan yang mengandung sayuran dan merah makanan berlemak.

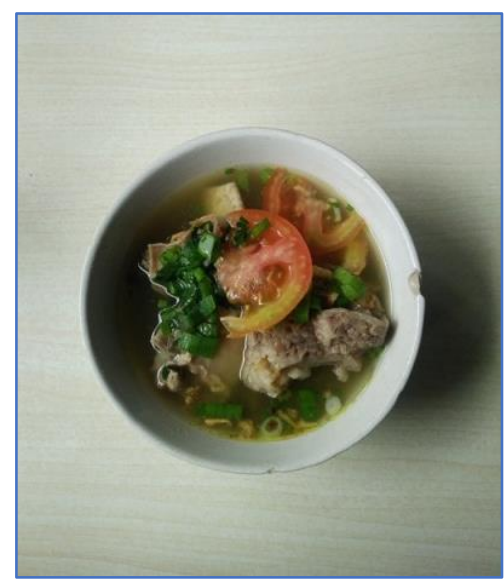

\section{Gambar 5 Data sample hidangan kedua}

\section{Keterangan:}

Pada gambar 5 adalah dataset yang digunakan untuk pengujian kedua. Data sample berupa satu mangkok sop iga, makanan tersebut banyak mengandung kolestrol.

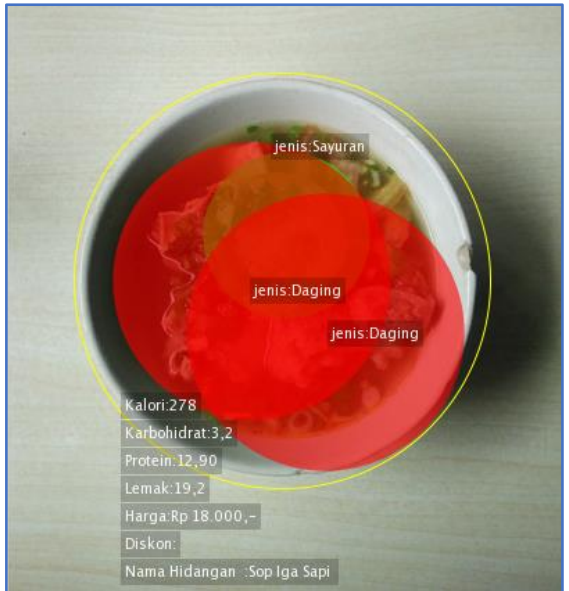

\section{Gambar 6 Hasil pengujian makanan yang mengandung kolestrol}

\section{Keterangan :}

Pada gambar 6 hasil pengujian pada makanan yang banyak mengandung kolestrol. Sistem menampilkan data kolestrol dengan lingkaran yang berwarna merah, pada tampilan visual kolestrol mencapai 228 gram dan merupakan angka yang lumayan tinggi kadar kolestrolnya.

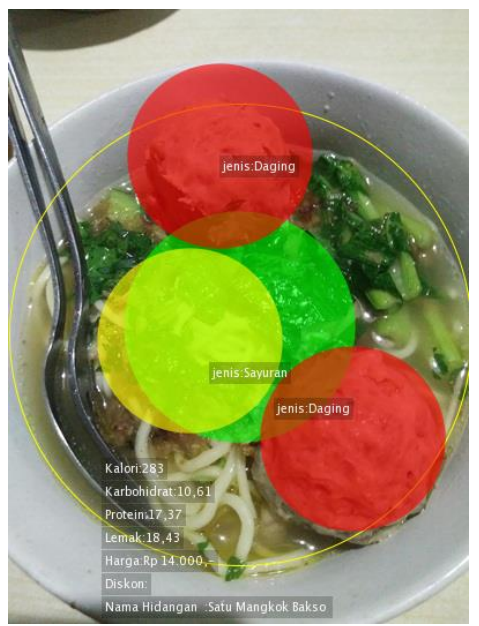

\section{Gambar 7. Hasil pengujian makanan ketiga}

\section{Keterangan:}

Pada gambar 7 adalah pengujian dengan komposisi makanan yang lebih bervariatif. Sistem membaca jenis makanan yang berbeda, warna merah menunjukan jumlah kalori yang berbeda dan warna kuning menunjukan jumlah nilai protein, warna hijau 
menunjukan jumlah protein yang terdapat pada mie instan.

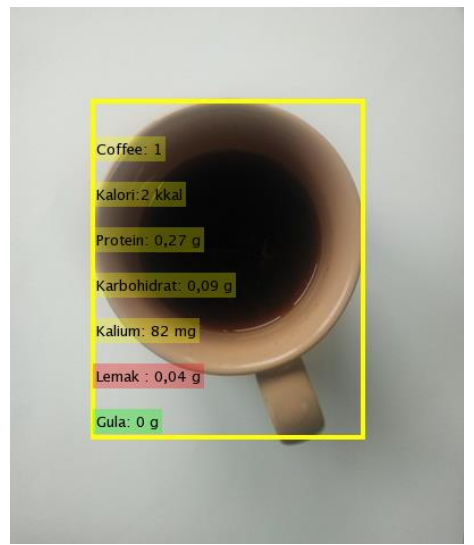

\section{Gambar 8 Hasil pengujian pada jenis minuman}

\section{Keterangan :}

Pada gambar 8 di atas pengujian sistem pada minimun kopi. Pada sistem menampilkan jumlah kalori nilai protein pada secangkir kopi, sehingga informasi yang didapatkan berguna dan disesuaikan dengan kadar kaffein yang dibutuhkan oleh tubuh.

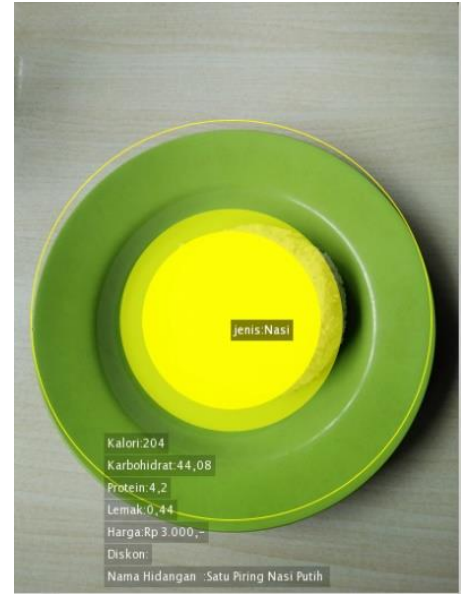

Gambar 9 Hasil pengujian pada nasi

\section{Keterangan:}

Pada pengujian gambar 9 sistem ini adalah proses pengujian sistem pada semangkuk nasi. Sistem memberikan output dengan lingkaran berwarna kuning yang menunjukan makanan yang mengandung banyak protein dan karbohidrat dengan nilai sajian 204 kalori.

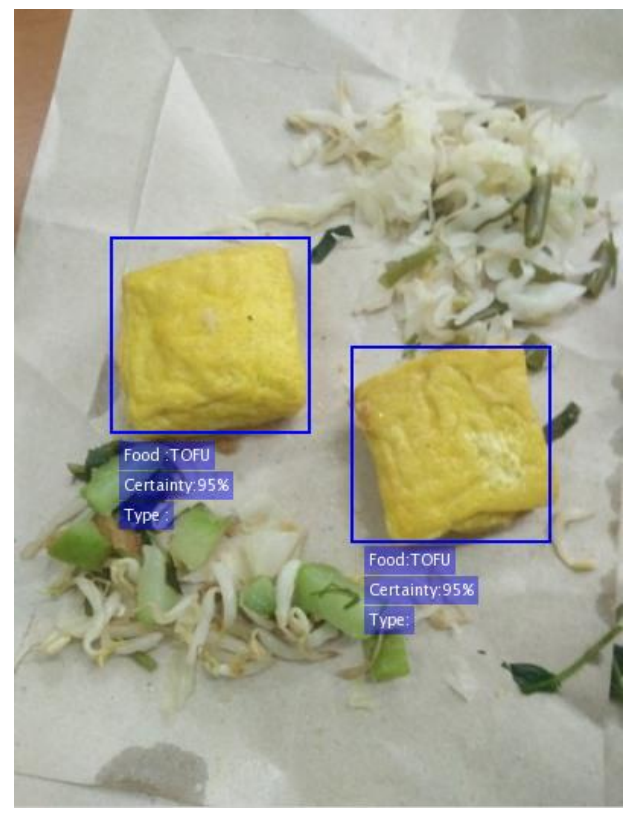

\section{Gambar 10 Hasil pengujian makanan salad}

\section{Keterangan :}

Pada gambar 10 adalah proses penerapan aplikasi deep learning pada perangkat mobile. Pada aplikasi tersebut sistem mampu membaca objek dalam hal ini jenis hidangan tahu dan menampilkan tingkat akurasi pembacaan data dengan keterangan "certainty".

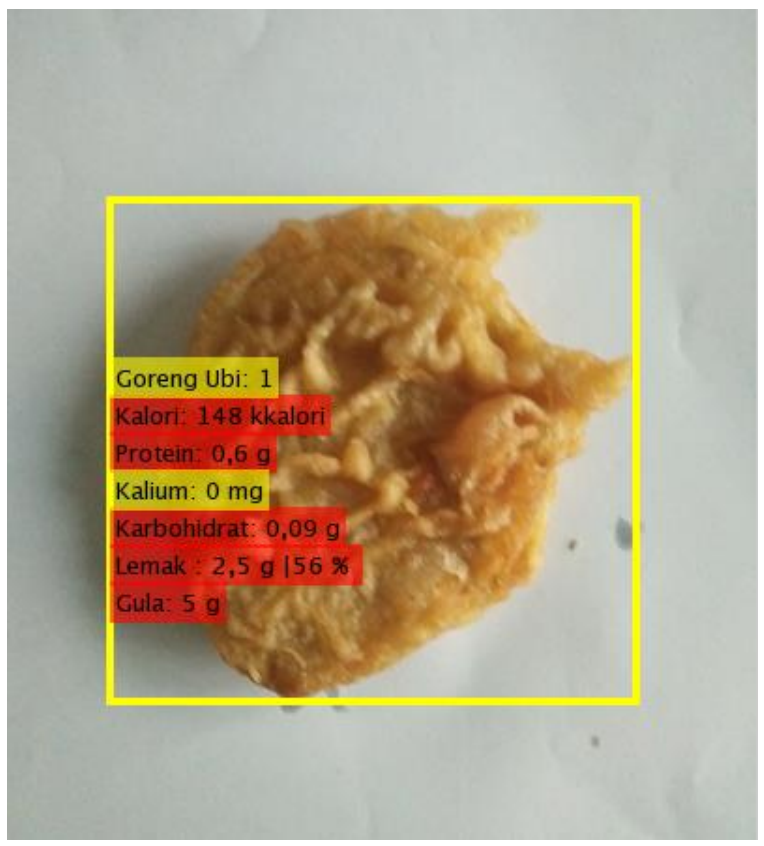

Gambar 11 Hasil pengujian makanan gorengan 


\section{Keterangan :}

Pada gambar 10 di atas jenis dan ketegori makanan yang dijadikan bahan ujicoba adalah gorengan. Pada percobaan bisa terlihat aplikasi mengenali jenis makanan yaitu gorengan ubi dan menampilan nilai nutrisi makanan tersebut, dari mulai nilai kalori, nilai protein, nilai karbohoidrat dan lain-lain. Tanda warna merah pada tampilan visual menandakan kadar nutrisi yang tinggi. Pada contoh di atas bisa terlihat nilai kadar lemak antara 2,5 gram dan kadar gula mencapai 5 gram pada satu gorengan. Dengan mengetahui kadar nutrisi tersebut maka kita harus berhati-hati dalam mengkonsumsi gorengan.

\section{KESIMPULAN DAN SARAN}

Kesimpulan dari pengujian sistem bisa disimpulkan bahwa sebuah kantin yang menerapkan teknologi Deep Learning Neural Network. Konsep ini dapat mempermudah proses pembayaran dan pembacaan nutrisi, bahkan pelanggan akan mendapatkan data dari nilai komposisi gizi dari setiap hidangan yang disajikan. Informasi nilai gizi tersebut bisa digunakan sebagai bahan manajemen untuk mengatur sikap dan pola makan sehingga kita bisa menerapkan pola hidup yang sehat di tengah kesibukan dan aktivitas yang padat.

Saran untuk penelitian selanjutnya adalah ditambahkan data dan minuman yang lebih bervariatif, sehingga menambah nilai jual dari kantin tersebut menjadi lebih tinggi. Konsep kantin pintar ini bisa ditambahkan dengan rekomendasi makanan sehat yang lain, sehingga nilai makanan yang kita konsumsi semakin terjaga dan seimbang.

\section{REFERENSI}

Doyen SAHOO;Hao WANG;Ke SHU;Xiongwei WU;Hung LE, "FoodAI: Food image recognition via deep learning for smart food logging," in KDD '19 Proceedings of the 25th ACM SIGKDD International Conference on Knowledge Discovery \& Data Mining, 2019.

Weiqing Min; Shuqiang Jiang; Linhu Liu; Yong Rui; Ramesh Jain, A Survey on Food Computing, arXiv preprint arXiv, 2018.

Jeff Donahue, Yangqing Jia; Oriol Vinyals; Judy Hoffman; Ning Zhang;Eric Tzeng; Trevor
Darrell;; "A deep convolutional activation feature for generic visual recognition," in In International conference on machine learning, 2014.

Jason Yosinski; Jeff Clune; Yoshua Bengio; Hod Lipson, "Howtransferable are features in deep neural networks".

Jia Deng ; Wei Dong; Richard Socher; Li-Jia Li;Kai Li; Li Fei-Fei, "Imagenet:A large-scale hierarchical image database," IEEE Conference, p. 248-255, 2009.

Dixon, J. B. ;, "The effect of obesity on health outcomes Molecular and cellular endocrinology," Molecular and cellular endocrinology, vol. 316, no. 2, pp. 104-108, 2010.

Lowe, D.G;, "Object Recognition from Local ScaleInvariant Features," in In Proceedings of the ICCV'99, Corfu, Greece, 1999.

Amatul Bushra Akhi; Farzana Akter; Tania Khatun, "Recognition and Classification of Fast Food Images," Global Journals Type: Double Blind Peer Reviewed International Research Journal, vol. 18, no. 1, 2018.

A., T. , " Monitoring food intake in europe: a food data bank based on household budget surveys," European journal of clinical nutrition, 1992.

Ari Purno Wahyu, Heri Heryono, M. Benny Chaniago, Dani Hamdani

Jurnal Ilmiah Teknologi Informasi Terapan

Volume 6, No 2, 15 April 2020 